\title{
EEE
}

Homepage: http://publisher.uthm.edu.my/proceeding/index.php/eeee e-ISSN : 2756-8458

\section{Life Cycle Assessment and Performances of Revived Industrial Lead-Acid Batteries Through Regeneration Technology : Regeneration Technology}

\author{
Nursyaheera Sahruddin ${ }^{1}$, Asmarashid Ponniran ${ }^{1 *}$ \\ ${ }^{1}$ Faculty of Electrical and Electronics, \\ Universiti Tun Hussein Onn Malaysia, 86400 Parit Raja, Johor, 86400, \\ MALAYSIA
}

DOI: https://doi.org/10.30880/eeee.2020.01.01.009

Received 04 August 2020; Accepted 06 September 2020; Available online 30 October 2020

\begin{abstract}
The growing amount of battery production will produce more substances which increase the number of harmful chemicals to the environment such as carbon dioxide, nitrogen, and sulfur dioxide. Since most Malaysians are thrown their old batteries away and replace with new batteries. The recycled batteries and revived batteries are ways to reduce the number of batteries being disposed of. Hence this study aims to determine the carbon footprint and performances of revived industrial lead-acid batteries through regeneration technology. In this study, life cycle assessment is used as a method to assess environmental impacts on which carbon footprint associated with all the stages of a batteries' life through the regeneration technology. The three processes involved in regeneration technology which charging process, discharging process, and regeneration process to evaluated the voltage, capacity, and specific gravity. From the results, the revived industrial lead-acid batteries through regeneration technology are $199.91 \mathrm{kgCO} 2$-eq of a carbon footprint than recycled batteries and the discharge time of 6 batteries are increased from 3 hours 55 minutes to 5 hours after using the regeneration technology. Thus, it is confirmed the revived industrial lead-acid batteries through regeneration technology are to be used preferably in reducing the disposed of batteries.
\end{abstract}

Keywords: Regeneration Technology, Lead-Acid Battery, Life Cycle Assessment

\section{Introduction}

The battery is a device consisting of one or more electrochemical cells with external connections provided to power electrical devices [1]. There are two types of batteries used in many applications which are primary and secondary. Primary are identified as non-rechargeable which designed to be used once and discarded, and not recharged by electricity [2]. Alkaline battery and carbon-zinc battery are examples of the primary battery. Next, secondary batteries are rechargeable which depends on their capacity of being electrically recharged such as nickel-cadmium and lead-acid. The type of battery which mainly used for renewable energy is lead-acid battery for solar power and nickel-cadmium which are uninterruptible power source (UPS) for backup supply. Besides, lead-acid battery in SLI (starting, 
lighter, ignition) also widely used for automotive applications such as cars, trucks, buses, and many conventional vehicles. However, all batteries cannot last long due to their lifespan. The battery life is the period in which the battery retains the charge and capable of being recharged. The used battery that its lifetime reaches its end, the battery is cannot retain its charge and no longer capable of being discharged for a long time. Once the battery cannot reversible of the whole process and the battery has been through the sulfation process is defined as the dead battery. Besides, two ways to reduce the number of batteries being disposed of which revived batteries through regeneration technology and recycled batteries. However, recycled batteries production will produce carbon dioxide emissions which contributes to air pollution [3]. Moreover, a regeneration technology has been developed to restore the sulfated batteries and improve capacity like a new battery [4].

In this study, life cycle assessment (LCA) is used as a tool for evaluating the environmental impacts associated with all phases of a product's life in revived through regeneration technology and recycled lead-acid batteries [5]. By using the LCA method, the total carbon footprints produced by revived leadacid batteries and recycled lead-acid batteries are determined and compared to indicate which process has less produces the carbon footprint. Also, this study will determine the performance of revived industrial lead-acid batteries through regeneration technology. The three processes involved in regeneration technology which charging process, discharging process, and regeneration process to evaluated the voltage, capacity, and specific gravity.

\section{Methods}

This study will be divided into two objectives which are LCA and evaluation $\mathrm{f}$ revived industrial lead-acid battery through the regeneration technology. In objective one, the method of study for the LCA of the revived battery through regeneration technology using SimaPro software simulator was carried out according to determine the carbon footprint of revived lead-acid batteries and recycled leadacid batteries where includes four steps which are goal and scope definition, inventory analysis, impact assessment, and interpretation. In objective two, the detailed descriptions of the batteries performance testing will be described.

\subsection{Objective 1: LCA process using SimaPro software simulator}

This study follows the LCA technique standardized by ISO 14040 and ISO14044 instructions. The LCA process included four steps which are goal and scope definition, inventory analysis, impact assessment, and interpretation in SimaPro software simulator. The purpose of LCA in this study is to determine the total carbon footprint produced by revived industrial lead-acid batteries through the transportation process, charging process, discharging process, and regeneration process for reducing the dispose of batteries. The results from the revived lead-acid battery will be compared with recycled leadacid batteries to indicate the used preferably in reducing the disposed of batteries: Figure 1 shows the flow chart of objective 1 for LCA process using SimaPro software simulator.

\subsubsection{First step: goal and scope of the LCA study in SimaPro software simulator}

The aim of this study is to evaluate the Life Cycle Assessment (LCA) of revived battery using regeneration versus the recycled batteries in order to quantify and compare the environmental benefits for both process. Second, to assess the environmental impacts including transportation, charging process, discharging process and regeneration process. Next to promote better environmental performance through the regeneration process and emissions from product. Lastly to reduce the environmental impact of products throughout their life cycle by propose environmentally friendly.

Assessing the life cycle of the environmental impacts of a revived battery using regeneration technology based on the following parameters and conditions. The type of the battery were studied in LCA is industrial lead-acid battery which are $8 \mathrm{v}$ and $170 \mathrm{Ah}$ The functional unit would be used in the LCA of the lead-acid battery is $35 \mathrm{~kg}$ for one battery. Next, the study will covered from gate to gate of 
the product which covers the selected stages of the life cycle of the product system as shown in Figure 1. Thus, the product system boundary for this study is secondary products which is used battery. The boundaries of the systems studied are from the product use to re-distribution as shown in Figure 1.

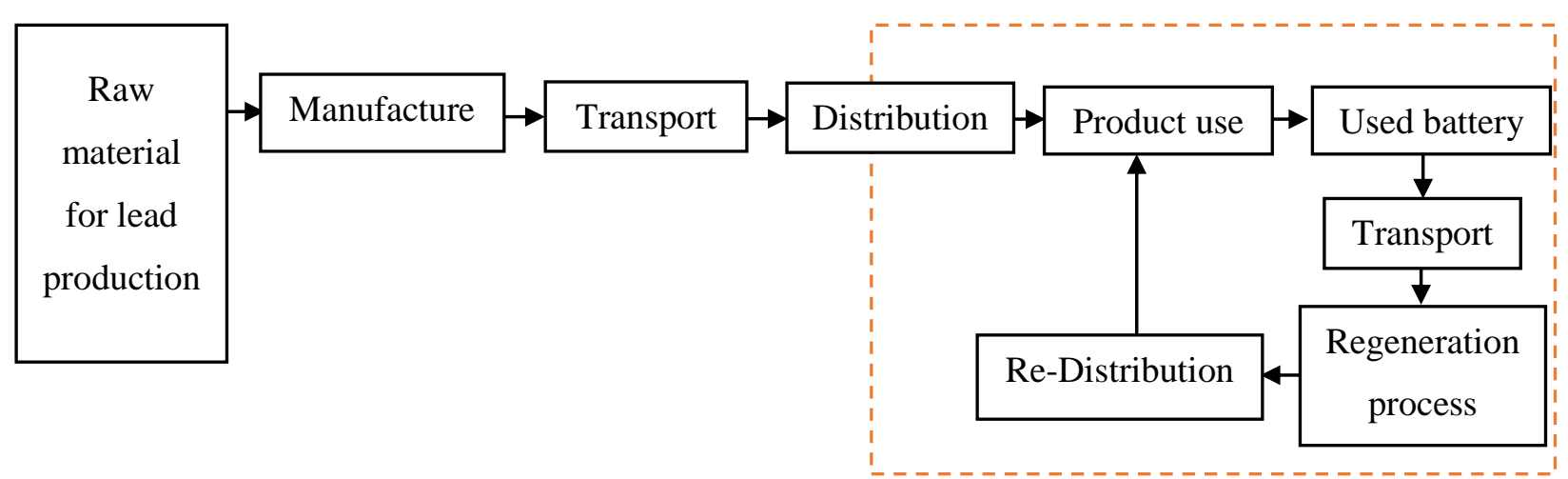

Figure 1: Product systems

\subsubsection{Second step: Life cycle inventory (LCI)}

The information that is outside the scope of the manufacturing process or cannot be stored directly, such as data resources, electricity, and transportation is secondary data sourced. The database of the LCA in this study is measured energy consumption per unit mass using the SimaPro software simulator. The data source is divided into two phase which are transportation phase and regeneration phase.

The transportation phase which deliver the new battery to market.such as the battery is deliver to dealers and franchise. In this study, this phase is include deliver the used battery to regeneration process, and the process of redistribution to the customer, The LCI data for transportation for two way is shown in Table 1 which Perak to Kuala Lumpur is choose.in this study. The data of fuel in SimaPro software simulator is set $0.28 \mathrm{~L} / \mathrm{Km}$.

Table 1: The LCI data for transportation phase

\begin{tabular}{cc}
\hline Data & Parameter \\
\hline \hline Diesel $(\mathrm{L} / \mathrm{Km})$ & 0.28 \\
Distance $(\mathrm{km})$ & 484 \\
Total diesel $(\mathrm{L})$ & 135.52 \\
\hline
\end{tabular}

The regeneration phase will covered the charging process, discharging process, and regeneration process. Moreover, this phase is use machine to complete all the process. Table 2 is shows the calculated energy produced by three process which are charging process, discharging process, and regeneration process.

Table 2: Energy produced by three machines

\begin{tabular}{cl}
\hline Processes & Total energy $(\mathrm{Wh})$ for machine \\
\hline \hline Charging process & $=17 \mathrm{~A} \times 57.6 \mathrm{~V} \times 10 \mathrm{~h}=9792 \mathrm{Wh}$ \\
Discharging process & $=(30 \mathrm{~A} \times 48 \mathrm{~V} \times 5 \mathrm{~h})+10 \%=7920 \mathrm{Wh}$ \\
Regeneration process & $=21 \mathrm{~kW} \times 78 \mathrm{~h}=1638 \mathrm{KWh}$ \\
\hline
\end{tabular}

\subsubsection{Third step: Life cycle impact assessment (LCIA)}

At this stage, the impact category used is environmental impact of the product system was assessed by separating the types of impact which are global warming and climate change. The damage category is divided into three which are to the human health, resource availability, and ecosystem quality. The method that used in LCA is ReCiPe method in SimaPro software simulator where mid-point impact and end-point impact would be analyse in this stage. 


\subsubsection{Fourth step: Interpretation}

At this stage, a sensitivity analysis is carried out to determine the reliability of the obtained data and is usually provided in the form of a percentage of change or an absolute deviation. The sensitivity analysis in this stage is the lead-acid batteries recycle are possible has high environmental impact than a revived lead-acid batteries through regeneration technology.

\subsection{Objective 2: Battery performance test}

In this part, the process of charging, discharging and regeneration process will be explained. Figure 3 shows the process to be carried out to determine battery performance. Besides, all the processes are explained in flow chart as shown in Figure 2.

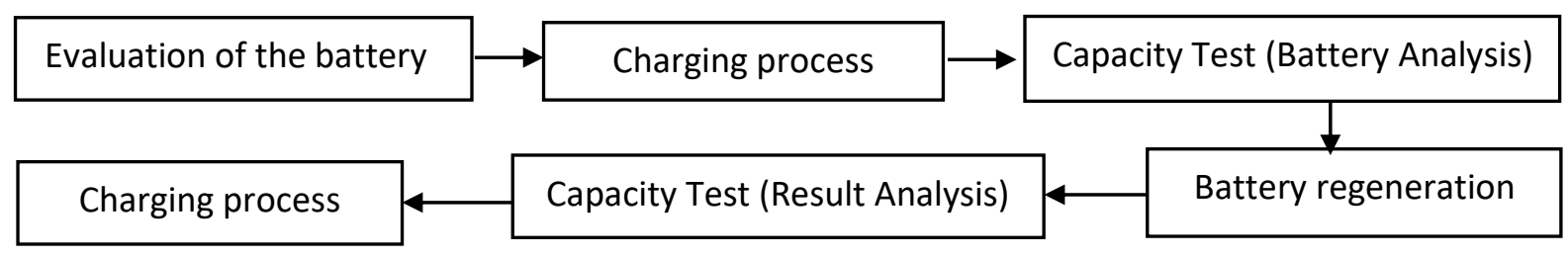

Figure 2: Revived industrial lead-acid process

\subsubsection{Evaluation of the battery}

The lead-acid batteries used in this study were used for golf carts. The nominal voltage of leadacid battery is $8 \mathrm{~V}$ where has 4 cells and the nominal capacity of the battery is $170 \mathrm{AH}$ as shown in Table 3. To evalaute the performances, 6 batteries are connected in series to become one battery bank.

Table 3: Lead-acid battery data

\begin{tabular}{cc}
\hline & Parameter of lead-acid battery \\
\hline \hline Type & Lead-acid \\
Voltage & $8 \mathrm{~V}$ \\
Capacity & $150 \mathrm{AH}$ \\
& $170 \mathrm{AH}$ \\
\hline
\end{tabular}

Before charging the batteries, check the specific gravity for each cell by using refractometer. The parameter in the charging machine is set as shown in Table 4 and charge for 10 hours.

Table 4: Parameter for charging machine

\begin{tabular}{cc}
\hline & Parameter Name \\
\hline \hline End Voltage & $(8 \mathrm{~V} \times 6)+20 \%=57.6 \mathrm{~V}$ \\
Max Amp. & $170 \mathrm{AH} \div 10 \mathrm{H}=17 \mathrm{~A}$ \\
End Amp. & $2.4 \mathrm{~A}$ \\
Time & $10 \mathrm{H}$ \\
\hline
\end{tabular}

\subsubsection{Capacity test (battery analysis)}

The discharge process is called capacity test for battery analysis. Before discharge process the lead-acid battery, $2 \mathrm{~V}$ wireless modules is used to measure the cell voltage for each batteries. The data from wireless modules is transmit into discharge machine or capacity tester and continue the discharging process for 5 hours. Next, set the parameter for the discharging process in the capacity tester as shown in Table 5. Lastly, choose the battery that have lower than $8.20 \mathrm{~V}$ as reference voltage for regeneration process 
Table 5: Parameter for capacity test machine

\begin{tabular}{cc}
\hline & Discharging Parameter \\
\hline \hline Capacity & $170 \mathrm{AH}$ \\
Hour Rate & $5 \mathrm{H}$ \\
Capacity Set & $145 \mathrm{AH}$ \\
Time Set & $5 \mathrm{H}$ \\
Battery Low & $1.7 \mathrm{~V} \mathrm{x} \mathrm{4} \mathrm{cell}=6.8 \mathrm{~V}$ \\
Capacity & $170 \mathrm{AH}$ \\
Group Low & $6.8 \mathrm{~V} \times 6$ batteries $=40.8 \mathrm{~V}$ \\
Battery Sum & 6 \\
\hline
\end{tabular}

\subsubsection{Regeneration Process}

After discharging the batteries, regeneration machines is set to regenerate the lead-acid batteries. as shown in Table 6 . The regeneration process would completely break down the lead sulfates on the plates and convert them back to lead oxides, lead, and by recombining with water to re-form acid without losing the hydrogen and oxygen gasses that make up the water. The process will take a minimum of 48 hours and a maximum of 72 hours depends on the condition of the batteries.

Table 6: Parameter for regeneration machine

\begin{tabular}{cc}
\hline \multicolumn{2}{c}{ Regeneration Parameter } \\
\hline \hline Battery Voltage & $48 \mathrm{~V}$ \\
Battery cell & $8 \mathrm{~V}$ \\
Capacity & $170 \mathrm{AH}$ \\
\hline
\end{tabular}

\subsubsection{Capacity test (test analysis) and Charging}

Procedure for capacity test which result analysis is same as capacity test (battery analysis). The purpose of the test is to evaluate the performance of the battery before and after the regeneration process. The battery that has a value lower than $6.80 \mathrm{~V}$ after discharge 5 hours is consider as bad battery.

\section{Results and Discussion}

The results and discussion are explained in this section. The comparison of carbon footprint or carbon dioxide between the LCA of revived industrial lead-acid batteries and recycle lead-acid batteries, and revived industrial lead-acid batteries performance tests through regeneration are discussed in this study.

\subsection{Results of life cycle assessment}

A carbon footprint is defined as the total emission caused by carbon dioxide equivalent that can be calculated using the relevant 100-year Global Warming Potential (GWP) The study shows that both processes produce only 3 types of GHG covered by the Kyoto Protocol which are is carbon dioxide, methane, and sulfur hexafluoride. The carbon footprint produced by the revived industrial lead-acid battery through regeneration technology using SimaPro software simulator are shown in Table 7.

Table 7: Carbon footprint result for revived industrial lead-acid batteries through regeneration technology

\begin{tabular}{ccccc}
\hline GHG & Designation & LCA Value (kg) & $\begin{array}{c}\text { GWP-100year } \\
\text { coefficient }\end{array}$ & CO2-equivalent $(\mathrm{Kg})$ \\
\hline $\begin{array}{c}\text { Carbon dioxide } \\
\text { (fossil) } \\
\text { Methane }\end{array}$ & $\mathrm{CO} 2$ & 187.78724 & 1 & 187.78724 \\
$\mathrm{CH} 4$ & 0.433 & 28 & 12.12
\end{tabular}




\begin{tabular}{cccc} 
Sulphur & $4.9 \times 10^{\wedge}-8$ & 228 & $1.1172 \times 10^{\wedge}-5$ \\
Hexafluoride & - & - & 199.91 \\
Total GWP & - & & \\
$(\mathrm{kgCO} 2-\mathrm{eq})$ & & & \\
\hline
\end{tabular}

Table 7 shows the total GWP produced by revived industrial lead-acid batteries is $199.91 \mathrm{KgCO} 2-$ eq for $1020 \mathrm{Ah}$. Thus, $0.1960 \mathrm{KgCO} 2$-eq for $1 \mathrm{Ah}$ of battery. Carbon dioxide occurred because of fossil fuels from transportation. The methane is burned to produce heat or generate electricity for the charging process and regeneration process and electrical equipment produced the sulphur hexafluoride. However, this impact is strongly dependent on the way electricity and total energy of the machine are produced. Likewise, the greenhouse gases (GHG) also released by recycled batteries as shown in Table 8 .

Table 8: Carbon footprint result for recycled batteries through the recycling process

\begin{tabular}{ccccc}
\hline GHG & Designation & LCA Value (kg) & $\begin{array}{c}\text { GWP-100year } \\
\text { coefficient }\end{array}$ & CO2-equivalent (Kg) \\
\hline $\begin{array}{c}\text { Carbon dioxide } \\
\text { (fossil) }\end{array}$ & $\mathrm{CO} 2$ & 1197 & 1 & 1197 \\
$\begin{array}{c}\text { Methane } \\
\text { Sulphur }\end{array}$ & $\mathrm{CH} 4$ & $2.64 \times 10^{\wedge}-6$ & 28 & 7.392 \\
$\begin{array}{c}\text { Hexafluoride } \\
\text { Total GWP }\end{array}$ & - & $9.31 \times 10^{\wedge}-5$ & 228 & 0.021 \\
$(\mathrm{kgCO} 2-\mathrm{eq})$ & & - & - & $1,204.41$ \\
\hline
\end{tabular}

Table 8 shows the total carbon footptint of recycled batteries is 1,203.41 KgCO2-eq for $1020 \mathrm{Ah}$. Therefore, $1.1807 \mathrm{kgCO} 2$-eq is released for $1 \mathrm{Ah}$ of battery recycling. It means the recycled batteries are released $0.9847 \mathrm{KgCO} 2$-eq than the revived batteries. As a result, recycled batteries released more GWP than revived batteries.

Next, life cycle impact analysis (LCIA) is measured by using ReciPe method characterization model which provided indicator scores for different impact categories. Therefore, the LCI results are classified into three areas of protection which are human health, ecosystems and resources that correspond to the impact categories. The revived industrial lead-acid battery through regeneration technology has revealed that it generates the largest negative impact in the area of protection of resources (6.55), followed by human health (3.86) and ecosystems (1.56). Besides, revived batteries and recycled batteries LCIA produce 17 midpoint impact based on the analysis by the SimaPro software simulator with ReciPe characterization model. The revived batteries produce a total of 25.75954 point of LCIA midpoint based on single score. This value contributes mainly fossil depletion, climate change human health, particulate matter formation, climate change ecosystems, and human toxicity.

Next, recycled batteries produce a total of 913.7486 point of LCIA midpoint based on single score. The top 6 factors contribute to this total are human toxicity, metal depletion, fossil depletion, particulate matter formation, climate change human health, and climate change ecosystems as shown in Figure 5. Main reason of this contributing factor is due to the 3 process which are recycling, transportation and remanufacturing. The recycled batteries produce more GWP due to its recycling process involve crushing and separation, pre-treatment and lead smelting. The difference of LCIA midpoint impact for both processes ar shown in Figure 3. 


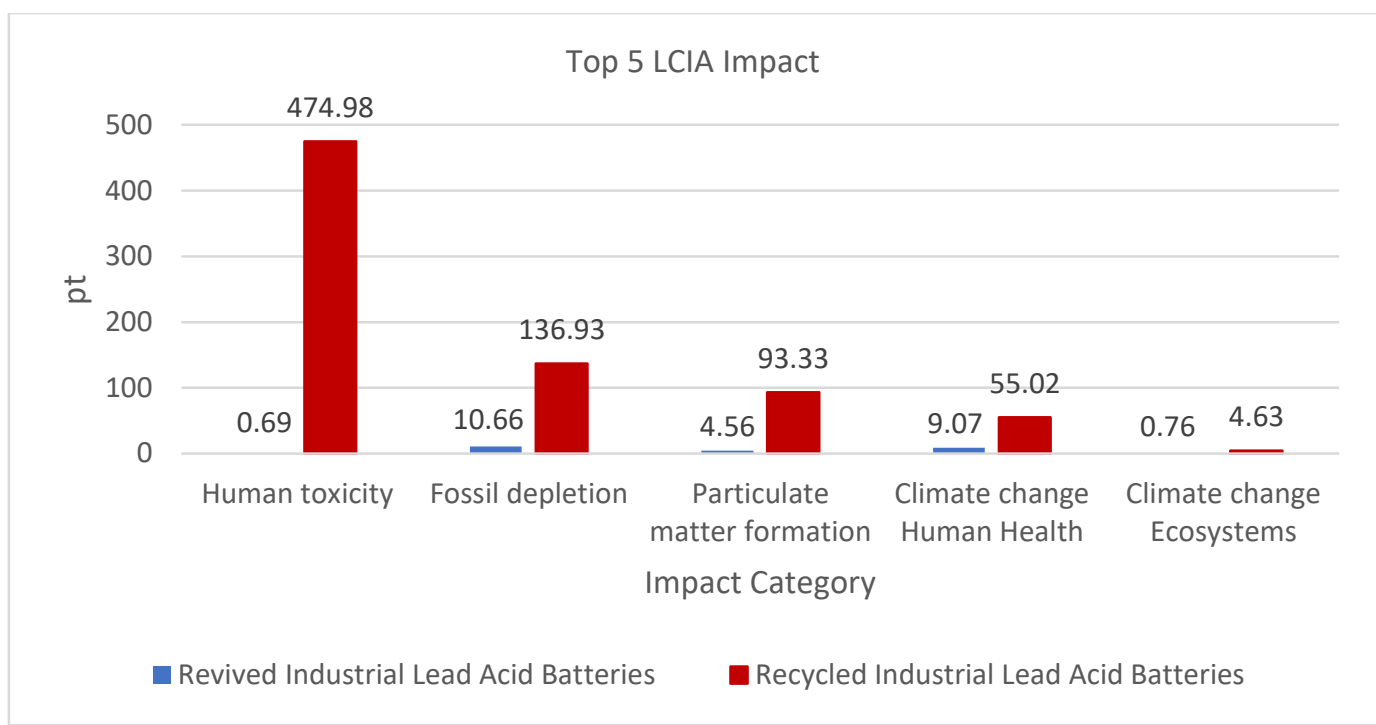

Figure 3: LCIA midpoint impact graph for revived industrial lead-acid batteries and recycled industrial lead-acid batteries

\subsection{Performances results of revived lead-acid batteries through regeneration technology}

The lead-acid battery will fails operate due to the accumulation of sulfate at negative plate of the battery. However, regeneration technology can helps the battery to revive its performance and can achieve better cycle life. The objective of this study to analyze voltages, capacities and specific gravities of revived industrial lead-acid batteries through regeneration technology. The battery bank which consists of 6 batteries are having the same initial specifications, same design, and the same manufacturer are examined in three process as shown in Table 9.

Table 9: Test specification for three process

\begin{tabular}{|c|c|c|c|c|}
\hline Processes & $\begin{array}{l}\text { Number of } \\
\text { batteries }\end{array}$ & $\begin{array}{c}\text { Voltage for each } \\
\text { battery }\end{array}$ & Time (hours) & $\begin{array}{c}\text { Capacity for each } \\
\text { battery }\end{array}$ \\
\hline Charging & 6 & $8 \mathrm{~V}$ & $10 \mathrm{H}$ & $170 \mathrm{AH}$ \\
\hline Discharging & 6 & $8 \mathrm{~V}$ & $5 \mathrm{H}$ & $170 \mathrm{AH}$ \\
\hline Regeneration & 6 & $8 \mathrm{~V}$ & Up to $48 \mathrm{H}$ & $170 \mathrm{AH}$ \\
\hline
\end{tabular}

Before the battery going through the regeneration process, the value of voltage for each battery is measured as shown in Table 10. From the results, it shows the voltage decrease in every minutes due to the power loss during the discharge test. Nonetheless, the batteries is stop working at 235 minutes due to the zero voltage in battery number 5 and 6 . This is due to the progressive accumulation sulfate at negative plate of the battery where the chemical reaction of sulphate acid is not release of two conducting electrons that create electric field. Therefore, the time bank battery to discharge are 235 minutes or 3 hour 55 minutes.

Table 10: Voltage of batteries before regeneration process

\begin{tabular}{cccccccccc}
\hline $\begin{array}{c}\text { Time } \\
(\mathrm{min})\end{array}$ & 0 & 30 & 60 & 90 & 120 & 150 & 180 & 220 & 235 \\
\hline \hline 1 & 8.361 & 8.070 & 8.008 & 7.932 & 7.850 & 7.757 & 7.677 & 7.562 & 7.527 \\
2 & 8.562 & 8.181 & 8.118 & 8.040 & 7.964 & 7.890 & 7.818 & 7.712 & 7.682 \\
3 & 8.348 & 8.065 & 7.991 & 7.916 & 7.841 & 7.765 & 7.691 & 7.577 & 7.543 \\
4 & 8.300 & 8.035 & 7.964 & 7.891 & 7.810 & 7.732 & 7.655 & 7.532 & 7.494 \\
5 & 8.416 & 8.069 & 8.000 & 7.934 & 7.870 & 7.802 & 7.729 & 7.617 & 0.000 \\
6 & 8.440 & 8.049 & 7.984 & 7.916 & 7.842 & 7.757 & 7.650 & 6.006 & 0.000 \\
\hline
\end{tabular}


Next, the battery bank went through the regeneration process for 48 hours. In this process, the accumulation of sulphate on the negative plate will break to form sulphuric acid again and the plates are reconstituted. Table 11 shows the voltages of 6 batteries are decrease in minutes due to the power used for the machine to operate. At 300 minutes, the batteries is stop working due to the value of voltage in battery number 1 and 4 is below than $6.8 \mathrm{~V}$. Normally, lead-acid battery will stop discharge when the value of voltage is $1.75 \mathrm{~V}$ in cell. Therefore, the discharge time for the battery bank are 300 minutes or 5 hours.

Table 11: Voltage of batteries after regeneration process

\begin{tabular}{cccccccccccc}
\hline $\begin{array}{c}\text { Time } \\
\text { (min) }\end{array}$ & 0 & 30 & 60 & 90 & 120 & 150 & 180 & 210 & 240 & 270 & 300 \\
\hline \hline 1 & 8.412 & 8.22 & 8.056 & 7.979 & 7.902 & 7.805 & 7.708 & 7.599 & 7.490 & 7.339 & 5.120 \\
2 & 8.592 & 8.38 & 8.166 & 8.098 & 8.030 & 7.964 & 7.898 & 7.8225 & 7.747 & 7.655 & 7.541 \\
3 & 8.437 & 8.26 & 8.077 & 7.999 & 7.920 & 7.8265 & 7.733 & 7.6305 & 7.528 & 7.400 & 7.191 \\
4 & 8.404 & 8.24 & 8.072 & 7.996 & 7.920 & 7.8265 & 7.733 & 7.625 & 7.517 & 7.373 & 6.034 \\
5 & 8.505 & 8.31 & 8.122 & 8.0575 & 7.993 & 7.9105 & 7.828 & 7.738 & 7.648 & 7.545 & 7.410 \\
6 & 8.592 & 8.40 & 8.216 & 8.1505 & 8.085 & 8.013 & 7.941 & 7.861 & 7.781 & 7.693 & 7.592 \\
\hline
\end{tabular}

Regeneration process involving the sending of low frequency and high-powered electrical pulses which break down the crystalline layer formed by amorphous lead sulphat. From the result on Table 10 and 11, it is confirmed that voltage of battery bank after regeneration took a long time to discharge than before regeneration process. Besides, there has the remain voltage in each battery on battery bank after regeneration even though the battery bank takes longer to discharge than before the regeneration process. This is prove that, the accumulation of sulphate on the negative plate has broken to sulphuric acid.

In addition, the results in Table 10 shows that battery number 5 and 6 have less lower voltage than other batteries. But, voltage of both batteries are increased after through the regeneration process as shown in Table 11. At 240 minutes, the voltage in before regeneration process is $0 \mathrm{~V}$ but after regeneration the value is $7.648 \mathrm{~V}$ for battery number 5 . For battery number 6 , the voltage in before regeneration process is $0 \mathrm{~V}$ but after regeneration the value is $7.781 \mathrm{~V}$ at 240 minutes.

Next, Table 12 shows the capacity of 6 batteries before and after regeneration in percentage. The percentage of battery number 5 and number 6 after regeneration increased $26 \%$ from $74 \%$ to $100 \%$. Capacity in battery number 2 is constant $100 \%$ before and after regeneration. The capacity in battery number 3 and 4 is increased $1 \%$ after regeneration process. Capacity in battery number 1 is decreased from $98 \%$ to $96 \%$ due to the discharge time of battery. Before regeneration, the discharge time is 3 hour 55 minutes while after regeneration is 5 hours. Therefore, time of discharge also can affect the capacity of battery.

Table 12: Capacity of batteries in percentage

\begin{tabular}{ccc}
\hline Batteries & Before & After \\
\hline \hline 1 & $98 \%$ & $96 \%$ \\
2 & $100 \%$ & $100 \%$ \\
3 & $99 \%$ & $100 \%$ \\
4 & $98 \%$ & $99 \%$ \\
5 & $74 \%$ & $100 \%$ \\
6 & $74 \%$ & $100 \%$ \\
\hline
\end{tabular}

A $8 \mathrm{~V}$ battery container usually has 4 cells. In this study, 6 batteries are used in the performance testing which has 24 cells. The specific gravity solution in a battery consists of $65 \%$ water and $35 \%$ sulfuric acid where the pure sulfuric acid is 1.84 is diluted by distilled water too becomes 1.2 of specific gravity. The specific gravity of the cells increases as the batteries charge and decrease to a value near 
pure water as the battery discharged. Some of the aging effects on the battery cells is excessive sulphurization on the plates. Table 13 shows the value of specific gravity for each cell in the batteries. After the regeneration process, the specific gravity of 5 cells are increased.

Table 13: Specific gravity for each cell

\begin{tabular}{ccc}
\hline Cell & Initial & Final \\
\hline \hline 1 & 1.19 & 1.28 \\
2 & 1.18 & 1.25 \\
3 & 1.15 & 1.27 \\
4 & 1.12 & 1.25 \\
5 & 1.17 & 1.29 \\
6 & 1.18 & 1.29 \\
7 & 1.18 & 1.3 \\
8 & 1.18 & 1.3 \\
9 & 1.2 & 1.26 \\
10 & 1.18 & 1.27 \\
11 & 1.19 & 1.27 \\
12 & 1.13 & 1.26 \\
13 & 1.2 & 1.26 \\
14 & 1.14 & 1.25 \\
15 & 1.19 & 1.27 \\
16 & 1.17 & 1.27 \\
17 & 0 & 1.29 \\
18 & 1.17 & 1.28 \\
19 & 0 & 1.28 \\
20 & 0 & 1.28 \\
21 & 1.14 & 1.3 \\
22 & 0 & 1.3 \\
23 & 0 & 1.31 \\
24 & 1.14 & 1.3 \\
\hline
\end{tabular}

\section{Conclusion}

In this study, the life cycle assessment of revived industrial lead-acid batteries through regeneration technology successfully determines the carbon footprint of the revived industrial lead-acid battery in Malaysia. This objective was achieved by using SimaPro software simulator were accounting and management from gate to gate that considers all of the aspects of resource use and environmental releases associated with an industrial system. From the results, revived lead-acid batteries produce a total of carbon footprint $199.91 \mathrm{KgCO} 2$-eq and recycled batteries are 1,203.41 $\mathrm{KgCO} 2$-eq. Next, revived batteries produce a total of 25.75954 point while recycled batteries produce a total of 913.7486 point of LCIA midpoint. Based on the LCA results, regeneration technology which revived industrial lead-acid batteries is to be used preferably in reducing the disposed of batteries than recycled batteries.

Next, the second objective is succeed when the voltage of 6 batteries are increased after using the regeneration technology. Two batteries which battery number 5 and 6 are recovered from accumulation of sulphate at negative plate. Besides, the discharge time of the batteries also increased 1 hour 5 minutes from 3 hours 55 minutes to 5 hours. Moreover, capacity of 4 batteries are increased to $100 \%$ and battery number 4 is increased from $98 \%$ to $99 \%$. This objective has been proved when the value of specific gravity increased after through the regeneration technology. Finally, the results show the improvement in performances of revived industrial lead-acid batteries through regeneration technology in buggy applications. 


\section{Acknowledgement}

The authors express their sincere gratitude to the Faculty of Electrical and Electronics, Universiti Tun Hussein Onn Malaysia (UTHM) for the use of facilities and equipment supports.

\section{References}

[1] "Electric Battery," Wikipedia, 16 September 2019. [Online]. Available: https://en.wikipedia.org/wiki/Electric_battery. [Accessed 27 September 2019]

[2] "Primary Cell," Wikipedia, 16 August 2019. [Online]. Available: https://en.wikipedia.org/wiki/Primary_cell. [Accessed 27 September 2019]

[3] J. S. a. L. Gaines, "A Review of Battery Life-Cycle Analysis: State of Knowledge and Critical Needs," Chicago, 2010

[4] Y.-J. Yu, "Revolutionary Battery Regeneration Technology," Recycling: Reduce, Reuse \& Recycle, Vol. 6, no. 4, p. 41, 2017

[5] "Life Cycle Assessment," Wikipedia, 22 September 2019. [Online]. Available: https://en.wikipedia.org/wiki/Life-cycle_assessment. [Accessed 27 September 2019] 